\title{
Deliberative and Non-Deliberative Negotiations
}

\section{Citation}

Mansbridge, Jane. 2009. Deliberative and Non-Deliberative Negotiations. HKS Faculty Research Working Paper Series RWP09-010, John F. Kennedy School of Government, Harvard University.

\section{Published Version}

http://web.hks.harvard.edu/publications/workingpapers/citation.aspx?Publd=6574

\section{Permanent link}

http://nrs.harvard.edu/urn-3:HUL.InstRepos:4415943

\section{Terms of Use}

This article was downloaded from Harvard University's DASH repository, and is made available under the terms and conditions applicable to Other Posted Material, as set forth at http:// nrs.harvard.edu/urn-3:HUL.InstRepos:dash.current.terms-of-use\#LAA

\section{Share Your Story}

The Harvard community has made this article openly available.

Please share how this access benefits you. Submit a story.

\section{Accessibility}


酤 HARVARD Kennedy School

Faculty Research Working Papers Series

Deliberative and Non-deliberative Negotiations

Jane Mansbridge

John F. Kennedy School of Government - Harvard University

April 2009

RWP09-010

The views expressed in the HKS Faculty Research Working Paper Series are those of the author(s) and do not necessarily reflect those of the John F. Kennedy School of Government or of Harvard University. Faculty Research Working Papers have not undergone formal review and approval. Such papers are included in this series to elicit feedback and to encourage debate on important public policy challenges. Copyright belongs to the author(s). Papers may be downloaded for personal use only. 


\title{
Deliberative and Non-deliberative Negotiations $^{1}$
}

\author{
Jane Mansbridge
}

The classic statements of deliberative democratic theory defined deliberation in opposition to negotiation. As deliberative theory has developed, that opposition has weakened. The normative terms of that relation, however, are as yet unclear. Building on work reformulating the regulative ideals for deliberative democracy (Mansbridge et al. forthcoming), this paper argues that four previously excluded forms of agreement are themselves "deliberative." One is simple convergence on an outcome. The other three -incompletely theorized agreements, integrative negotiation, and fully cooperative distributive negotiation -- are forms of deliberative negotiation. The "regulative ideals" of these forms of negotiation, that is, the standards to which we should aspire in their practice even when full achievement is impossible, meet all the criteria for deliberation. This paper aims at reformulating the regulative ideal of deliberative democracy to incorporate these forms of agreement.

\footnotetext{
1 This paper draws from and expands on Mansbridge et al., forthcoming in the Journal of Political Philosophy, which makes the case for including self-interest in deliberation and in a shorter form discusses the deliberative and non-deliberative forms of negotiation. I thank my co-authors on that article, James Bohman, Simone Chambers, David Estlund, Andreas Follesdal, Archon Fung, Cristina Lafont, Bernard Manin, and José Luis Martí, as well as the other participants in the Workshop on the Role of Bargaining, Negotiation, Compromise, and Voting, particularly Joshua Cohen, Philip Pettit, and Dennis Thompson, for discussions and subsequent comments that helped inspire and improve this work. The paper has also benefited from comments by participants at a Stanford University workshop, a seminar jointly sponsored by the University of Pennsylvania and Temple University, a roundtable at the American Political Science Association, a faculty seminar at the Kennedy School, and a workshop conceived and organized by Mark Moore at the Hauser Center at the Kennedy School, with the participation of Jack Donahue, Archon Fung, Linda Kaboolian, Brian Mandel, Barbara Nelson, and James Sebenius. I also thank Carrie MenkelMeadow, whose What's Fair? (1990) introduced me to many of the articles on negotiation ethics referenced here. Finally, I am grateful to the Ash Institute for Democratic Innovation and the Safra Center for Ethics, both at the Kennedy School of Government at Harvard University, for supporting the original March 2007 workshop with its innovative deliberative format.
} 
Minimally, the deliberative ideal as a regulative ideal requires that deliberation meet several criteria. The deliberation should, ideally, be open to all those affected by a decision. The participants should have equal opportunity to influence the process, have equal resources, and be protected by basic rights. ${ }^{2}$ In the process of mutual justification, participants should treat one another with mutual respect. They should give reasons to one another that they think the others can comprehend and accept. They should aim at finding fair terms of cooperation among free and equal persons. They should speak truthfully. They should achieve their ends by a process of mutual justification, not try to change others' behavior through the exercise of coercive power. This paper focuses on this last criterion, interpreting coercive power to mean the threat of sanction or use of force. ${ }^{3}$

Non-deliberative negotiations, by contrast, are characterized by the significance of coercive power in their interactions. Many, perhaps most, legislative negotiations are of this form, which Raiffa terms "cooperative antagonist” negotiation. Participants in such negotiations use threats, such as the threat of leaving the negotiation, as standard and accepted features of the interaction. They may also use forms of parliamentary strategy, such as the manipulation for political success of Robert's Rules of Order, to achieve success. Democracies often implicitly authorize the legislative use of such nondeliberative forms of negotiation, but the norms appropriate to these forms and the role morality that might accompany them have not received much theoretical scrutiny. This paper suggests that because cooperative antagonist negotiations have some characteristics of both deliberation and legitimate aggregation, they should be judged on both sets of normative criteria. According to deliberative criteria, the negotiations should be as open, fair, mutually respectful, mutually justificatory, and non-coercive as possible. According to aggregative criteria, when coercive power is exercised it should be based on as close as possible to equal constituent power.

\footnotetext{
${ }^{2}$ For the ideal of equality in deliberation, see Knight and Johnson 1997.

${ }^{3}$ Mutual justification may simply be the antonym for coercive power; that is, these two categories may exhaust the methods for producing practical agreement. It is not necessary to settle this question here. See below and Mansbridge et al. forthcoming for a definition of coercive power. The argument for these forms of negotiation being deliberative does not rest on the criterion of absence of coercive power; it can rest on the other criteria.
} 
This paper addresses the ideals relevant to democratic processes that result in a binding decision. Although deliberation might be defined broadly as "communication that induces reflection on preferences [and values and interests] in a non-coercive fashion," deliberative democracy is a subcategory of deliberation that requires a binding decision. ${ }^{4}$ The production of a binding democratic decision in the circumstances of politics, which include conflict, requires a combination of deliberative forms, including classic deliberation, convergence, incompletely theorized agreements, integrative negotiation, fully cooperative distributive negotiation. It also requires non-deliberative forms of democracy, including cooperative antagonist negotiation and aggregation through voting.

\section{The classic antithesis}

In the political theory of the last half of the twentieth century, three separate strands of thought on deliberation -- the Habermasian, civic republican, and Rawlsian - all concluded that deliberation is antithetical to negotiation.

In his early The Structural Transformation of the Public Sphere, Jürgen Habermas contended that the expansion of the "public" by the mid-nineteenth century caused a “structural transformation” from common to competing private interests, and thus from reason to coercion and "bargaining." Before this structural transformation, a politics prevailed in which "an organization of society strictly oriented to the general interest...[kept] conflicts of interest...to a minimum” ([1962] 1989, 131). In its best moments deliberation was "based on a justifiable trust that within the public presupposing its shared class interest - friend-or-foe relations were in fact impossible” (131). After the transformation, "conflicts hitherto pushed aside into the private sphere now emerged in public. ... Laws [now]...corresponded more or less overtly to the compromise between competing private interests” (132-133). Once "the masses...succeeded in translating economic antagonisms into political conflicts” (146), “the foundation for a relatively homogeneous public” was "shaken,” “competition

\footnotetext{
${ }^{4}$ Definition of deliberation adapted from Dryzek 2000, 76; see Mansbridge et al. forthcoming on the requirement of a binding decision.
} 
between organized private interests" entered the political scene, and consensus "yielded to compromise fought out or simply imposed nonpublicly” (179).

[A]s soon as private interests, collectively organized, were compelled to assume political form, the public sphere ...was burdened with the tasks of settling conflicts of interest that could not be accommodated within the classical forms of parliamentary consensus and agreement; their settlements bore the mark of their origins in the market. Compromise literally had to be haggled out, produced temporarily through pressure and counterpressure and supported only through the unstable equilibrium of power constellations between state apparatus and interest groups. Political decisions were made within the new forms of "bargaining" that evolved alongside the older forms of the exercise of power: hierarchy and democracy (198). ${ }^{5}$

In the more than four decades since this work, Habermas's thought has evolved significantly, moving toward some acceptance in democratic politics of "strategic" action (aimed at winning) in addition to his preferred "communicative” action (aimed at

5 In this approach Habermas agreed with Carl Schmitt, who wrote in 1923 that the Weimer parliament was no longer an "assembly of wise men...who sought to convince each other through arguments in public discussion on the assumption that the subsequent decision reached by the majority would be what was true and right for the national welfare" (Schmitt [1923] 1988, quoted in Habermas 1989, 205-206). Schmitt believed that he had witnessed the demise of a tradition of "public discussion, that is, reason," which, quoting Eugene Forçade (1853), he contrasted to "force" (Schmitt, [1923] 1988, 49). "For the sense of justice of an entire historical epoch," he wrote, openness and discussion "seemed to be essential and indispensable. What was to be secured through the balance guaranteed by openness and discussion was nothing less than truth and justice itself. One believed that naked power and force - for liberal, Rechtstaat thinking, an evil in itself, 'the way of beasts,' as Locke said - could be overcome through openness and discussion alone, and the victory of right over might achieved. There is an utterly typical expression for this way of thinking: 'discussion in place of force.'” Having credited Eugene Forçade with this expression in a footnote, Schmitt also cited Lamartine (1831 and 1850) on the contrast between discussion and power or force (Schmitt [1923] 1988: 103, n. 49). A few years later, he wrote: "To discussion belong shared convictions as premises, the willingness to be persuaded, independence of party ties, freedom from selfish interests." Discussion "does not simply mean negotiation," but stands in contrast to "calculating particular interests and the chances of winning and with carrying these through according to one's own interests." These self-interested goals may be "also directed by all sorts of speeches and declarations. But these are not discussions in the specific sense" (Schmitt [1926] 1988, 4-6). He then referred to the "definitions of parliamentarism which one still finds today in Anglo-Saxon and French writings and which are apparently little known in Germany, definitions in which parliamentarism appears essentially as 'government by discussion' [...]" (Schmitt [1926] 1988: 7). (The phrase, "government by discussion," which derives from Harold Laski, appears in English and is repeated in English two paragraphs later, underscoring Schmitt's point that he is drawing from what he conceives as a non-Germanic tradition. I thank Isaac Nakhimovsky for noting out that these words appear in English.) 
understanding) and, as discussed in the next section, toward encompassing bargaining and negotiation in his democratic theory. Yet he has never accorded the word “legitimate” to strategic action, with its concern for acquiring and exercising political power, or to bargains or negotiations based on strategic action. ${ }^{6}$

In a different theoretical tradition, contemporary civic republican theory, based on a revision and development of themes in writers in the Renaissance city states and the English seventeenth century, articulated a similar view. In 1985, Cass Sunstein drew a stark contrast between the "republican" view that "through discussion people can, in their capacities as citizens, escape private interests and engage in pursuit of the public good” (1985, 31) and the "pluralist” endorsement of a "struggle among self-interested groups," in which politics is "a process of conflict and compromise among various social interests” (32). Unlike pluralists, he wrote, “republicans will attempt to design political institutions that promote discussion and debate among the citizenry; they will be hostile to systems that promote lawmaking as "deals" or bargains among self-interested private groups” (1988, 1539; also 1554). Here too discussion and deliberation is posed as antithetical to conflict, compromise, and bargaining.

Finally, in a third philosophical tradition based on the work of John Rawls, Joshua Cohen has argued that the outcomes of deliberation are democratically legitimate only when the deliberation aims to arrive at “a rationally motivated consensus” $(1989,23)$ “focused on the common good" (24), whose outcomes could be the object of "reasoned agreement” among free and equal citizens (22). ${ }^{7}$ As he put it, even "an ideal pluralist scheme, in which democratic politics consists of fair bargaining among groups each of which pursues its particular or sectional interest, is unsuited to a just society” (18). In later work he also explicitly contrasted “deliberative politics” to “a politics of bargaining” (1996, 423).

\section{The opening}

6 See below, note 10 .

7 Note that the last criterion is hypothetical rather than actual, serving as, in essence, a measure of justice. 
Contemporary theorists exploring the concept of deliberation have moved significantly away from the classic ideal in this, as in other, respects. ${ }^{8}$ Amy Guttman and Dennis Thompson, for example, argue that "Deliberative democracy makes ample room for bargaining. So long as all sides in a political controversy accept moral reciprocity [mutually acceptable reasons and accommodation based on mutual respect] as a constraint on their reasons for action, bargaining is a deliberatively legitimate way of resolving political conflicts that would otherwise remain unresolved. Bargaining thus constrained is completely consistent with deliberation” $(1996,71)$. In their view, we should reject bargaining "only when the parties fail to consider the merits of the collective results of their individual deals," including both the main agreement and the side deals (72).

By 1989, Habermas himself was writing that "Modern societies also are characterized by the need for regulations that impinge only on particular interests. While these matters do require regulation, a discursive consensus is not needed; compromise is quite sufficient in this area. Let us keep in mind, though, that fair compromise in turn calls for morally justified procedures of compromising” $(1989,48)$. In his major work, Between Facts and Norms, a few years later he underscored that democracies often face instances in which no "generalizable interest or clear priority of some one value" is "able to vindicate itself” ([1992], 1996, 165). In those cases, citizens may deliberatively establish the possibility of solving some of their differences through a negotiated agreement, assessing when and how negotiation is adequate and possible. In his words, democracies require, in addition to deliberation, bargains that deploy "threats and promises...material resources, manpower and the like," but the bargaining power should be distributed equally among the parties (166). ${ }^{9}$ He thus includes "procedurally regulated bargains" as an acceptable part of "rational political will-formation" (168). He distinguishes between deliberation to "a rationally motivated consensus" and bargaining, "that is, negotiation between success-oriented parties who are willing to cooperate" (165), on the basis of two criteria. First, the parties in bargaining and negotiation are

8 E.g., Bohman 1998, Chambers 1996, Thompson 2008, Mansbridge et al. forthcoming.

${ }^{9}$ Here Habermas quotes Elster 1991 [reprinted and updated 2001] on threats and promises. See also [1992] 1996, 108-9, and earlier, [1983] 1990, 72. 
oriented to success. Second, "Whereas a rationally motivated consensus (Einverständnis) rests on reasons that convince all the parties in the same way, a compromise [derived from bargaining] can be accepted by the different parties each for its own different reasons” (166, emphasis in original).

Simone Chambers has also begun the process of integrating bargaining into a Habermasian framework of legitimate democracy. She has advanced the contingent and non-dichotomous guideline that "the more the issue under public discussion involves deep foundational issues of justice the more important rational consensus becomes” (Chambers 1996, 187). Yet “fair compromises" are legitimate "to the extent that citizens believe there are good reasons to settle” for the procedural rules that govern them (188). More recently, she has defined "a legitimate political order" as "one that could be justified to all those living under its laws” (2003, 308, emphasis in original). Such justifications cover bargaining whenever citizens have been able "to deliberate and decide when and where bargaining is a fair and appropriate method of dispute resolution" (2003 p. 309). ${ }^{10}$

In short, in the view of many contemporary theorists, deliberation can either include or have a productive relationship with bargaining and negotiation. This article explores more fully the kinds of bargains and negotiations that may themselves be termed “deliberative” and their relationship with non-deliberative but deliberatively authorized

10 Chambers attributes this view to Habermas ([1992] 1996). The passages in which Habermas includes "procedurally regulated bargains” as part of "rational political will-formation” ([1992] 1996, 168) and discusses briefly how citizens can deliberatively assess when negotiation should be instituted support this attribution. On the other hand, Habermas never uses the word "legitimacy" in this context. His wording suggests the more rigorous claim that statutes are legitimate only when they "can [können] meet with the assent of all citizens in a discursive process of legislation that in turn has been legally constituted” (Habermas [1992] 1996, 110). (The word können, or “can,” is not as hypothetical as könnten [“could”] nor as imperative as dürften or müssen ["must”]. Having choosen können for the "democratic principle” but könnten for the "discourse principle," Habermas seems not to have intended the democratic principle to be taken hypothetically. I thank Cristina Lafont (personal communication) for this interpretation of Habermas's intent and Isaac Nakhimovsky for investigating the implications of the German. Benhabib 1996 contrasts Rawlsian (hypothetical) with Habermasian (actual) theories of deliberation. But Michael Rosen (1999) argues that although Habermas consciously aims to distinguish himself from Kant by, in a sense, making "hypothetical consent" actual through deliberation, this position is not practically tenable. Ultimately, therefore, Rosen suggests, Habermas never decides whether or not the agreement required may be hypothetical. Estlund 2006 understands Habermas's requirement as hypothetical. Because of this ambiguity, it is unclear whether or not Habermas now accepts non-deliberative bargains and negotiations (with their inevitable component of coercive power) as legitimate democratic processes and the statutes that arise from such processes as legitimate. 
democratic forms of decision-making. The bargains and negotiations that, in the ideal, meet all the criteria for ideal deliberation are characterized procedurally by mutual justification, mutual respect, equality, and the search for fairness. They do not involve the exercise of coercive power. They include four forms of communicative agreement convergence, incompletely theorized agreements, integrative negotiation, and fully cooperative distributive negotiation. 


\section{Power as a key distinction}

In the deliberative forms of decision-making, power - in the sense of coercive power - is ideally absent. ${ }^{11}$ Because, as Foucault points out, every human being is constituted by power relations, including coercive power relations and at the same time exercises coercive power over others, the absence of coercive power is a regulative ideal, not fully achievable in practice. $^{12}$

We can understand power in general as A's preferences or interests causing (or changing the probability of) outcomes, and coercive power as A's preferences or interests causing B to do (or changing the probability that B will do) what B would not otherwise have done through the threat of sanction or the use of force. ${ }^{13}$ Coercive power arises only when the preferences or interests of A and B conflict. Of the two forms of coercive power, the threat of sanction and the use of force, only the threat of sanction engages the will of the coerced. If I threaten you with a sanction ("Leave this room or I'll shoot you”), you can always accept the sanction and deprive me of what I want. You will your action, although you do not prefer it and it is not in your interests. Force differs from the threat of sanction in not engaging the will of the coerced. When I use force, I achieve my goal without a choice on your part (I carry you out of the room, kicking and screaming). Because force works against your interest without engaging your choice, it includes any structuring of alternatives that, unknown to you, is detrimental to your interests.

\footnotetext{
${ }^{11}$ In Habermas's early formulation, for example, ideal deliberation embodies "the power-free flow of communication" ([1962] 1989, 202) and the public sphere is one in which "the influence of power is suspended" (144), meaning power as coercion. This section of the paper is condensed from or duplicates Mansbridge et al. forthcoming; see also Mansbridge and Shames 2009. The deliberative forms of negotiation can also be distinguished from the cooperative antagonist forms with other criteria such as reciprocity (Guttman and Thompson 1996) and mutual justification.

12 Some of the mystique of Foucault's analysis derives from conflating power as capacity with power as coercion.

${ }^{13}$ More strictly, we define power in general as "the actual or potential causal relation between the preferences or interests of an actor or set of actors and the outcome itself," a definition adapted by the addition of the words in italics from Nagel's 1975 definition, which improves on those of Weber and Dahl by including anticipated reactions and not requiring intent. The categories of the threat of sanction and use of force derive from Bachrach and Baratz 1963. The definition of coercive power as applying only in situations of conflicting interests derives from Lukes 1974; it thus does not apply to the unequal capacity to persuade when interests do not conflict (see Knight and Johnson 1997).
} 
The power that is antithetical to deliberation is not power in general, which could include the simple capacity to act, but coercive power, defined as the threat of sanction/use of force against the others' interests. Lying is a form of force, thus of coercive power. A's lying leads B to act, without B's willing it, against B's own interests in ways that B would otherwise not act. Other forms of manipulation, in ways that structure alternatives against the others' interests, are also forms of force.

In the four deliberative forms of communicative agreement that I argue can join classic deliberation, coercive power is ideally absent. Even in a fully cooperative distributive negotiation, individuals state and pursue their self-interests in a context of the search for fairness and mutual accommodation, so that what might in another context become promises or threats are instead suggestions for compensation or predictions of negative consequences. ${ }^{14}$ The difference is subtle but real. In the deliberative ideal, including the ideal instantiated in a fully cooperative negotiation, coercive power should have no effect. Even the status quo would ideally have no weight other than persuasive weight (for example, in an argument that something has worked up till now, it will probably work in the future).

The ideal of fully absent power is not only impossible to achieve; it is even hard to envision. We are all the products of power relations and exercise power by our very presence in the world. In reality, however, power differences among the participants play more or less important roles in affecting the outcomes of an interaction. The regulative ideal of absent power prescribes reducing the threats of sanction and the use of force to a minimum.

In the deliberations on the common good that comprise much of deliberative democracy, mutual justification and the absence of coercion ideally characterize the interaction. This is the classic ideal. In addition, four deliberative forms of communicative agreement meet deliberative criteria but have not traditionally been

\footnotetext{
14 See Elster 1995 for the distinction between offers/predictions and promises/threats. The difference appears when one party puts on the table a prediction of her own probable negative reaction to another's action and the other asks, "Is that a threat?" The question asks whether the first party intends to cause the negative consequence she predicts in order to produce the desired action on the part of the other. The distinction is often hard to determine in practice. If the negative reaction that A predicts advances her interests, it can be a form of "impersonal" power that threatens a sanction on B. Thus even predictions or warnings of this sort are not power-free.
} 
understood as forms of deliberation. Each of these processes ends in a kind of consensus, that is, a genuine agreement among participants that the outcomes are right or fair. In each the participants eschew the use of coercive power.

\section{Deliberative negotiations}

\section{Convergence}

One form of deliberation, conflict-free convergence, involves agreement on a single outcome, for the same reasons, but without any significant conflicts of opinion or interest in the process. Classic deliberation begins with conflicting opinions. But in the many instances of convergence, which this paper argues are also forms of deliberation, individuals enter the deliberation with opinions on what is good for the polity that do not greatly diverge, bring together facts and insights from their various sources of information, and converge on one option as the best. Although theorists often dismiss the many instances of this form of deliberation as "administration,” reserving the term “politics” for moments of conflict, in actual democracies - whether town meetings or national legislatures or even university faculty acting collectively - many important collective decisions have this relatively conflict-free character. Participants may enter with interests or opinions significantly diverge, but these opinions are often not fully formed or known to one another. The participants need to consider what information and interests each brings to the table and sort out what they think is best by talking with and listening carefully to one another. They need to reflect together, perhaps in depth, on their mutual preferences, values and interests. Their self-interests may turn out to be compatible, their opinions on the common good similar, or both. One member may make a good suggestion to solve a common problem, one or two others suggest modifications, and the group reach agreement. A committee may discuss an issue and unearth evidence, agree on recommendations, report to the group, and the full group agree. ${ }^{15}$ Such moments of convergence build mutual respect and trust. They teach each member about the strengths and weaknesses of the others. They generate collective agency, mutual

15 In the U.S. Congress, for example, a surprisingly high percentage of legislation is passed unanimously. 
respect, satisfaction and goodwill. They forge bonds on the basis of common action that can be draw upon in subsequent moments of conflict. They provide a critical glue within the political process. Not considering these moments part of the political process or part of "deliberation" distorts the analysis. Without these moments it becomes impossible to understand the full weave of the tapestry of any political decision.

\section{Incompletely theorized agreements}

An "incompletely theorized agreement" describes the conclusion to a form of deliberation to coordination that originates with conflicting opinions on the common good and concludes in agreement on a single outcome, but for different reasons. ${ }^{16}$ While convergence differs from classic deliberation in not originating with conflict, incompletely theorized agreements differ from classic deliberation in the parties not coming to agreement for the same reasons. In incompletely theorized agreements that are consonant with a deliberative ideal, the participants offer one another reasons for particular decisions. They may agree on some reasons, and on the generalizations associated with those reasons, but if so, these are, in the words of Joseph Raz (1986, 58), "low or medium level" generalizations around which individuals with profound disagreements over ultimate foundations can unite.

Cass Sunstein originally formulated this concept in the context of disagreements of opinion in the U.S. judiciary, and many of his arguments for the superiority of incompletely theorized agreements over attempts to develop encompassing theory are restricted to the judiciary, where modesty in approach has considerable democratic and practical backing. Yet he intends some of his arguments (perhaps not for the superiority of incompletely theorized agreements but at least for their dignity as forms of agreement) to apply more broadly within democratic deliberation. Sunstein's examples outside the judiciary of agreements that "are supportable by reference to diverse foundations" (1752)

\footnotetext{
16 Sunstein 1995; see also Sunstein 1996: 35-61. Bohman 1996, 80ff also argues for deliberative agreement on the basis of "different publicly accessible reasons" (83; also 92, emphasis in the original). Habermas, by contrast, requires that the process of producing a "rationally motivated consensus" exclude the different parties accepting the result "each for his own different reasons" ([1992] 1996, 166, emphasis in original). See also Pettit 2003.
} 
include legislative coalitions for laws that protect endangered species, grant unions a right to organize, and make abortion legal.

Sunstein gives as an example of a non-judicial incompletely theorized agreement the compromise reached by the members of the United States Sentencing Commission, who, in spite of having deeply divergent theoretical perspectives on punishment (some retributive, some based on deterrence), reached agreement on sentencing guidelines by deciding to use as a guide "typical, or average, actual past practice" (1995, 1744, citing Breyer 1988, 17).

Outside the judicial realm, Sunstein argues for incompletely theorized agreements on the grounds that they allow "citizens generally to find commonality -- and a common way of life -- without producing unnecessary antagonism” (1746). Such agreements "allow people to show each other a high degree of mutual respect, civility, or reciprocity," by agreeing not to discuss deeply contested issues fully "as a way of deferring to each other's strong convictions” (ibid). More basically, he argues from a foundational pluralism: "Human goods are plural and diverse, and they cannot be ranked along any unitary scale without doing violence to our understanding of the qualitative differences among those very goods” (1748).

Sunstein also argues that incompletely theorized agreements are more likely than fully theorized ones to preserve openness for future evolution. Moreover, he argues, "The abstract deserves no priority over the particular: neither is foundational; neither is harder or more real. A (poor or crude) abstract theory may simply be a confused way of trying to make sense of our considered judgments about particular cases, which may be much better than the theory” (1762). On the most practical level, he argues that with limited time, it is in many cases not possible to reach fully theorized agreements.

Human beings also have limited capacities for giving reasons for what they think is right or what they want. Participants in a deliberation, Sunstein writes, might sometimes know something without knowing the reasons for it. For example, one may know that this is Martin's face, and no other face, without knowing, exactly, why one knows that fact. Or one might know that a certain act would be wrong, without knowing, exactly, why it would be wrong. It is 
certainly possible to know that something is true without knowing why it is true (1755-6).

When participants have the kind of knowledge that often goes under the names of “wisdom, perception, or judgment” (1756), they may not be able to give persuasive reasons for their position. But in an incompletely theorized agreement, such reasons are not required.

Sunstein concedes that fuller theorization "in the form of wider and deeper inquiry into the grounds for...judgment” may be valuable or even necessary to prevent inconsistency, bias, or self-interest (1761). Because inconsistency is no small matter, "moral reasoners should try to achieve vertical and horizontal consistency, not just the local pockets of coherence offered by incompletely theorized agreements” (ibid.). A more fully theorized approach, he further concedes, might produce better outcomes. But fundamentally, he argues for incompletely theorized agreements on the grounds that in a plural society these agreements encourage "the demonstration of humility and mutual respect,” allowing participants to “avoid unnecessary controversies over fundamental commitments” (1761).

Sunstein concludes that in the judicial world, where modesty is a virtue for many role-specific reasons, "we ought not to think of incompletely theorized agreements on particulars as a kind of unfortunate second-best, adopted for a world in which people disagree, are confused or biased, and have limited time” (1768). In the political world, where these role-specific reasons for judicial modesty do not apply, a genuine agreement based on fully articulated reasons and larger principles seems superior to an equally genuine agreement based only on the coincidence of goals. So long as the participants remain open to challenging ideas and to change, by and large the more general the principles on which the reasons are based, the more likely the agreement is to serve as a useful and predictable guide to action. If conducted in a deliberative manner, however, incompletely theorized agreements have a respectable place within an ideal of deliberation.

Writing in 1995, Sunstein could not consider Gutmann and Thompson’s (1996) argument that when possible, engaging another in mutually reciprocal, respectful discussion of disagreements over fundamental commitments demonstrates an even deeper 
form of mutual respect. Yet in a sense, Gutmann and Thompson's own “economy of moral disagreement” has some affinity with incompletely theorized agreements. In both situations, participants agree on a conclusion without necessarily agreeing on the entire rationale for that conclusion. Gutmann and Thompson write, "In justifying policies on moral grounds, citizens should seek the rationale that minimizes rejection of the position they oppose. While ...integrity calls on citizens to accept the broader implications of their positions, this form of magnanimity tells citizens to avoid unnecessary conflict in characterizing the moral grounds or drawing out the policy implications of their positions." They add that citizens "also have an obligation to seek an economy of factual disagreement” $(1996,85)$. Thus while participants in deliberation have an obligation to engage in disagreement over fundamental commitments, they have a concomitant obligation to seek areas of moral convergence and not press their stand beyond what integrity requires into moral conclusions that other participants cannot accept.

Incompletely theorized agreements and the economy of moral disagreement differ from classic deliberation in not producing full consensus on an outcome for the same reasons. They do, however, fit well into a deliberative frame that requires mutual justification, mutual respect, fairness, and the absence of coercive power.

\section{Integrated solutions, integrative negotiation}

What management theorists call "integrated," or "win-win," solutions based on "integrative" negotiation, are, like incompletely theorized agreements, forms of coordination that originate with conflict and conclude with agreement on one outcome, but for different reasons. They differ from incompletely theorized agreements in taking more explicitly the form of a negotiation, dealing more frequently with differences in material interests, and stressing not coordination on existing goals but the creation of new "value." Mary Parker Follett, the political theorist and management theorist of the early twentieth century, first pointed out the possibility of what she termed "integrated" solutions to problems (Follett [1925]1942). Having conceived of the concept of integrated solutions, she gave as an example her wanting the window in a library shut to avoid a draft, while another patron wanted it open to get more air in the room. Her solution was to open the window in the next room, giving both parties what they wanted. 
No one lost and one of the two gained. Both parties, not just one, can also gain from fashioning a solution that fulfills their underlying desires in contrast to their original positions. Reaching such a solution requires sufficient thought to move from conflicting surface preferences (window open, window closed) to congruent deeper preferences (cooler, no draft) and to devise a solution, not originally in the thought patterns of either party, that satisfies both sets of deeper preferences. To come up with such alternatives, including alternatives to the issues under discussion that give each party more than each had realized was possible before the negotiation, good negotiators must enter as far as possible into the full situation of their counterparts in the negotiation. They need to be able to take the perspective of the other.

Integrated solutions have two parts. The first consists in identifying possible different valuations of the different aspects of the negotiation, a sine qua non for such solutions. ${ }^{17}$ Mary Parker Follett's example of the library window would not have been susceptible to integrative solution if the two parties had simply wanted different temperatures (two conflicting points on one scale) rather than cool air and no draft (two different and possibly compatible things). If Egypt and Israel are in conflict over the placement of a border, the problem as originally defined involves two points on the same scale, a clear zero-sum conflict. But if Egypt wants to maintain its national pride and sovereignty while Israel wants security, a demilitarized zone under Egyptian sovereignty gives each of the two parties much of what it wants. ${ }^{18}$ To achieve an integrated solution, the parties must value, and realize that they value, different aspects of the negotiation differently.

The second part of any integrated solution involves the search for alternate arrangements that "expand the pie," or "create value.” This search at the least suggests inputs that meet the needs of one party while being less costly than originally envisioned or not costly at all to the other. This search can also involve significant mutual learning

\footnotetext{
17 Wetlaufer (1996) argues that many texts exaggerate the prevalence of problems susceptible to such solutions, which can occur only when the parties have different valuations of the different aspects of the negotiation. He does not, however, give evidence for this empirical claim. See Lax and Sebenius (2006), Bazerman, Baron and Shonk (2001), and Thompson (2005) for many examples of problems with such different valuations that allow for integrative negotiation.

18 Fisher, Ury and Patton 1991, 41-42.
} 
through joint exploration. It can move the participants from a stance of "face to face against each other" to one of "side by side against the problem."19 The search begins with the recognition that the parties to the negotiation do not know what all the possibilities are for their proposed cooperation. It recognizes further that the parties in the negotiation are often the best placed, in their knowledge, expertise, contacts, and commitment, for engaging in this exploration of possibility, or "joint study tour." ${ }^{20}$ All negotiated agreements leave all parties no worse than the status quo and at least one better off. Integrative negotiation does far more: it engages the participants in cooperative activity in the very course of the negotiation.

Within a negotiation, the search for integrated solutions usually requires the parties to act in all the ways that deliberative theory promotes. Negotiation theorists David Lax and James Sebenius, for example, recommend "openness, clear communication, sharing information, creativity, an attitude of joint problem solving, and cultivating common interests" (1986, 32). They stress "being open, sharing information about preferences and beliefs, not being misleading about minimum requirements, and so forth.” They insist that "to create value, a negotiator needs to learn about her counterparts' interests and perceptions, to help them learn about hers, to foster ingenuity and creativity, and to blunt the escalation of conflict" (113, emphasis in original). These features do not differ from the central deliberative stances of mutual respect, empathy, and a search for understanding.

\section{Fully cooperative distributive negotiations}

In each of the previous forms of mutual discussion ending in agreement, no individual has to settle for an outcome less than he or she wants or thinks is right, whether in matters of the common good or self-interest. In a pure integrative agreement such as opening the window in the next room, for example, neither party has to compromise. Yet a genuine agreement that makes both parties more satisfied than the status quo can also derive from

19 Lax and Sebenius 1986, 113.

20 Kaboolian 2006, 56. 
compromises and bargains, the result of a distributive, or zero-sum, negotiation. ${ }^{21}$ In a distributive negotiation, the parties reach an agreement that is better for each of them than both the status quo and the other available alternatives, but all give up some part of what they want to get agreement. The difference between integrative negotiations and distributive negotiations is that integrative negotiations do not require compromise but distributive negotiations do.

In this analysis, the term "fully cooperative negotiations," borrowed from Howard Raiffa, will describe fully cooperative distributive negotiations. In a fully cooperative negotiation, Raiffa posits, the partners

have different needs, values, and opinions, but they are completely open with one another; they expect total honesty, full disclosure, no strategic posturing. They think of themselves as a cohesive entity and they sincerely want to do what's right for that entity. This would be true, for instance, of a happily married couple or some fortunate business partners. (Raiffa 1982, 18) ${ }^{22}$

In fully cooperative negotiations, the participants want not only to do what is right for their "cohesive entity." When their material or other interests conflict irreconcilably, they also want to do what is right for themselves individually. When they negotiate, there is no normative obstacle to their recognizing their own interests, identifying the distributive and zero-sum quality of the interaction, and seeing themselves as "partners in a hardheaded, side-by-side search for a fair agreement advantageous to each” (Fisher, Ury and Patton 1991, 37). ${ }^{23}$

In fully cooperative negotiation, both sides are "committed to finding fair terms of cooperation,” as Gutmann and Thompson say about deliberation in general $(1996,78)$.

\footnotetext{
21 I use the term "zero-sum” colloquially to include what strict game-theorists would call "constant-sum" and "zero-sum" games, in both of which my gain requires your loss. (Thanks to Joseph Mazor for this point.)

${ }^{22}$ Although Raiffa described "fully cooperative" partners only briefly in this one paragraph, to distinguish them from the "cooperative antagonists" of and for whom he was writing, he nevertheless believed that such a relationship could exist in practice, e.g. among married or "fortunate business" partners. We assume that fully cooperative negotiations can never be completely achieved in practice, but also assume that such relationships can be approached and can stand as a regulative ideal.

23 See Mansbridge et al. 2009 for the legitimacy of self-interest in deliberation.
} 
The parties want not only the process but the outcome to be fair. A major problem is that fairness takes many forms. As Fisher, Ury and Patton write (1991, 153), "In most negotiations there will be no one `right' or 'fairest' answer; people will advance different standards by which to judge what is fair.”24 They also point out, however, that this is not an insuperable problem: "When standards have been refined to the point that it is difficult to argue persuasively that one standard is more applicable than another, the parties can explore tradeoffs or resort to fair procedures to settle remaining differences" (154). In response to the multiplicity of forms of fairness, partners can explore tradeoffs among ideals of fairness or resort to fair procedures to settle the differences. ${ }^{25}$

As with many ideals, honesty and fairness are regulative ideals. Self-serving bias and other cognitive and emotional schemas keep human beings from seeing their own positions completely honestly, let alone conveying those positions to others without selfserving nuance. Similarly, human beings will gravitate toward conceptions of fairness that implicitly benefit them. Nevertheless, human beings can attempt and approach honesty and full disclosure.

In the regulative ideal, a fully cooperative negotiator is completely honest and disclosing. When a common good is possible with her partner(s), she pursues the common good. When conflicts cannot be resolved with integrated solutions, she searches for fair distributions. In the negotiation, she gives the other's interests equal weight with her own. ${ }^{26}$ But she does not give her own interests less than equal weight. And she understands that by not pursuing her own interests she may actually fail to do her part in the common effort to find the most integrative and the fairest solutions.

24 Many negotiation theorists make this point, e.g. Raiffa 1982; Lax and Sebenius 1986.

25 Fisher, Ury and Patton 1991, 153-4 suggest that participants can resort to fair division even to handle differences that arise from different perceptions of fairness. Carlos Nino gives as an example of different perceptions of fairness a discussion in a condominium whose elevator must be repaired. The lower-floor tenants might think, "Those who do not benefit from a service are not obliged to pay for it," while the upper-floor floor tenants think, "A condominium is a scheme of cooperation in which everybody pays for everything whether he directly benefits from it or not” $(1996,123)$. Facing such different perceptions, fully cooperative negotiators might, among other choices, split the difference (creating a fair division among competing fairness claims) by deciding that each should pay something but those who benefit most should pay more, look for precedents in other condominiums' practices, or draw analogies from other mixedbenefit solutions in their own condominium.

26 This criterion is not the same as making the other's interests one's own. If each participant made the other's interests completely her own, the two participants would not differ from one person. 
Like the classic deliberative ideal, the ideal of a fully cooperative negotiation can be approached but never fully achieved. One form of failure, ironically, is not to give one's own interests equal weight. The goal, difficult but not impossible to approach in practice, is for each to pursue the common good, but when interests conflict, recognize those conflicts and in negotiating them treat the other with respect and concern - ideally concern for the others' interests equal to concern for one's own - without neglecting one's own self-interests. Negotiators warn that friends and other individuals who trust one another and want to do right by their cohesive entity may fail to pursue their selfinterest fully enough to realize the gains that can be achieved in negotiation, because their concern for the relationship is so great that they hesitate to cause conflict (see e.g., L. Thompson 2005, 143).

\section{How "fully cooperative negotiation" solves the "negotiator's dilemma"}

In 1986, Lax and Sebenius articulated the "Negotiator’s Dilemma," which Scharpf (1997, [124]) describes as follows:

The successful joint search for better overall solutions requires creativity, effective communication, and mutual trust, whereas success in the distributive battle depends on strategic, and even opportunistic, communication and withholding of available information—and a good deal of distrust against potential misinformation.

Most negotiations will have integrative and distributive features. The integrative goal, from which both parties benefit, is to extend the boundary of possible solutions to encompass as many as possible of the "joint gains" the parties can create together. The distributive goal, from which one party may benefit at the expense of the other, is to agree on how to distribute those joint gains between the parties. In a non-deliberative setting, which Raiffa called "cooperative antagonist" negotiation, the very features of full disclosure and trust that contribute to good joint problem-solving at the first stage of integrative negotiation leave a negotiator vulnerable to exploitation at the second stage of distributive negotiation. 
A commitment to fully cooperative negotiation, when available, solves this problem. To the degree that the parties can commit reliably to fully cooperative negotiation, with its intrinsically motivated aim at a fair outcome, they can move easily between the integrative joint problem-solving mode and the distributive mode, each secure in the knowledge that the other will not exploit in the distributive negotiations the vulnerabilities exposed in joint problem-solving.

When achievable, fully cooperative negotiation is efficient. Societies striving for efficiency will thus foster institutions and norms that foster or approximate as far as practically possible the conditions for fully cooperative negotiation.

In the trade-off between strategic misrepresentation and full disclosure, the logic is simple: full disclosure on both sides increases the chances of information coming out of the interaction that will allow the negotiators to find creative solutions and "increase the pie." Non-disclosure creates only strategic advantage; it does not increase the pie. ${ }^{27}$

Honesty in negotiation therefore takes the form of a classic collective action problem (Cramton and Dees 1993): It is best for both parties if both are honest, but it (often) pays each individual even more to be dishonest when the other is honest. As with all collective action problems, the parties will benefit collectively if they, or the larger society, can find ways of making the cooperative move "pay" individually, either through internal sanctions (morality) or external sanctions (social or institutional rewards or punishments). By changing the individual reward structure to make dishonesty

\footnotetext{
27 Carrie Menkel-Meadow writes, “[E]xaggerations and failures to disclose information or to take the needs and preferences of the other side really seriously do not produce efficient solutions but often produce economic and social waste with incomplete information, falsely expressed preferences, and weak split-thedifference compromises” (2004, xxviii). She continues (in what is in essence a brief for fully cooperative negotiation), “Consider how much more efficient...negotiations might be if ...clients and negotiators [could] say what they really wanted, needed, or expected.... [We] already do this in negotiations with people we already trust (spouses, colleagues, partners, friends, children, some relatives, and some business associates, even with some 'intimate adversaries,' like trusted superiors at work or in long-term contractual relationships..., or with those with whom we are required to behave honorably (fiduciaries and accountants), with people whose help we need (doctors), or who interact with us frequently enough to know when we're telling the truth ('repeat players')" (xxix; see also Menkel-Meadow 1990 and Goodin 1996, 341 on the value of disclosure). This conclusion about the moral status and efficiency of disclosure requires several caveats. On the normative side, Donald Moon argues that "genuinely free and uncoerced" agreement requires that "participants...can resist the demand for self-disclosure" (1993, 95). On the efficiency side, many argue that parties to a negotiation should be able to withhold information that they produced with substantial investment on their part, in order to create an incentive for such investment, in analogy with a patent (Posner 2007, 111; Langevoort 1999 [398]).
} 
("defection" in the terminology of the collective action problem) less attractive than cooperation, these sanctions allow the individuals in the negotiation to reap the benefits of cooperation.

One significant external sanction against defection in the real world derives from reputation or other forms of effective signaling, which make it possible for others to refuse to enter into negotiations with individuals whom they perceive as dishonest. Whenever interactions with the structure of a collective action problem are voluntary, effective signaling allows the trustworthy to seek out the trustworthy, leaving the sharp dealers to negotiate only with one another - far less efficiently. ${ }^{28}$

Reputation helps move actual negotiators toward the fully cooperative state. The eighteenth century French diplomat François de Callières (1716) concluded:

It is a capital error, which prevails widely, that a clever negotiator must be a master of the art of deceit.... The negotiator will perhaps bear in mind that he will be engaged throughout life upon affairs of diplomacy and that it is therefore in his interest to establish a reputation for plain and fair dealing...[which] will give him a great advantage in other enterprises on which he embarks in the future” (quoted in Lax and Sebenius 1986, 147)

Adam Smith put the matter even more strongly: “The prudent man is always sincere, and feels horror at the very thought of exposing himself to the disgrace which attends upon the detection of falsehood" (1759, 350, quoted in Cramton and Dees, 1993, 369). Cramton and Dees comment, however, that "Smith overstates the case." Deception is likely to pay in non-deliberative negotiations when information asymmetry is great, verification is hard, the intent to deceive is hard to establish, interaction between the parties is infrequent, ex post redress is too costly, information about reputation is unavailable, unreliable, or very costly, the circumstances limit inferences about future behavior, or one party has little to lose or much to gain from attempting deception (idem.). These circumstances all limit the effectiveness of reputation in generating

${ }^{28}$ Gaulthier (1986) began to develop the logic of cooperators choosing one another against defectors in voluntary collective action dilemmas. Frank (1988) first developed the consequences of clear signaling when interaction in a collective action dilemma is voluntary. These practical advantages of moral behavior i create an "ecological niche" that can save from extinction moral behavior engaged in for intrinsic reasons (Mansbridge 1990). 
accurate signals and the consequent sanction of others' unwillingness to enter into negotiation.

The effectiveness of reputation in generating sanctions affects local norms regarding honesty and other cooperative behaviors. Geoffrey Hazard, for example, describes how in the United States local norms range from "the rural God-fearing standard” to "New York hardball.”29 Even James White, noted for his endorsement of deception in negotiation, agrees that "the costs of conformity to ethical norms are less in a small community” $(1980,921)$. When a community is small, most people will know by reputation who does not conform to community standards and can often protect themselves by refusing to enter into transactions with those individuals. Social sanctions other than the refusal to enter into agreements are usually also more available in a small community. ${ }^{30}$

In larger, more impersonal, communities, social sanctions are less effective and reputation is harder to establish informally. In these communities, solving collective action problems requires more formal institutions. Cramton and Dees (1993) point out several instances in which contemporary U.S. society has created institutionalized sources of reputational information, such as better business bureaus and credit rating bureaus, independent rating and evaluation services (e.g. Consumer Reports, Standard and Poor bond ratings, and the Good Housekeeping Seal of Approval), professional associations, and industry associations that give certificates of credibility (e.g. Certified Public Accountant). The function of these institutions is to make business as a whole more efficient by solving the dishonesty collective action problem through creating penalties for lying that make it even more expensive to lie than to tell the truth in

\footnotetext{
${ }^{29}$ These regional differences "were brought home to me dramatically when I entered the practice of law in Oregon after attending law school in New York City” (Hazard 1981, 133 n. 43).

${ }^{30}$ Lewicki and Robinson find significant differences among MBA students in the U.S. on the behaviors considered appropriate or not appropriate in negotiations. Ohio State University MBAs were significantly less likely than any other group of MBAs, including students in the U.S. from Europe, Asia, Latin America, and the Middle East, to say that various forms of strategic misrepresentation of information were appropriate. Self-identified "aggressive" (in contrast to "cooperative") personalities, men, and Harvard MBAs (in contrast to Ohio State University MBAs) were, on average, more likely than others to consider misrepresentation appropriate $(1998,675)$. Short-term socialization can also affect these norms. In a classic study, students in economics classes showed in the course of a semester significantly greater movement toward reported willingness to act dishonestly than students in a non-economics class. And as between two economics classes studied, the one that stressed game theory produced the greater movement (Frank et al. 1993).
} 
situations where otherwise lying would bring benefits. To the degree that larger societies are able to invent, relatively costlessly, more sources of reputational information that can apply in a large-scale world of strangers, the more those societies will be, overall, efficient and successful in comparison to other societies, by facilitating a collective move toward an approximation of fully cooperative negotiation.

Institutionalized rules and penalties, of course, invite participants to exploit the areas that the formal rules do not cover. Consider the U.S. law of fraud, an institution that helps solve the collective action problem of dishonesty. At present, according to this law, a "bargaining move is fraudulent [and thus illegal] when a speaker makes a (1) knowing (2) misrepresentation of a (3) material (4) fact (5) on which the victim reasonable relies (6) causing damages” (Shell 2006, 201). Under this law it can be illegal even to stay silent when "the negotiator makes a partial disclosure that is or becomes misleading in light of all the facts" or "has vital information about the transaction not accessible to the other side” (Shell 2006, 203, 204). Negotiation instructors thus often parse the five factors in the law carefully, both to alert negotiation students to the institutionalized rules that generate penalties for these actions and also to allow them to exploit the nuances that exempt other actions from penalty.

The law of fraud seems to have made illegal all the behaviors that could easily be monitored and documented. It has not, for example, tried to regulate dishonesty regarding internal states (such as one's own reservation price). Yet although legislators have often gone as far as possible in practice in legislating honesty, the law remains far from being able to guarantee fully cooperative negotiation.

With a "Code of Negotiation Practices for Lawyers," Roger Fisher has tried to create an informal institution that penetrates farther than the law can do into the unmonitorable arena of the mind. He suggests that lawyers voluntarily sign on to a proposed code, make public their adherence to it, and inform their clients of that adherence. The code is summed up by the general maxim, "[B]ehave toward those with whom you negotiate in ways that incorporate the highest moral standards of civilization" ([1985] 2004, 25). Although Fisher does not make this point, public adherence to such a code, backed by reputation, could in principle allow adherents to negotiate only with other adherents, reaping efficiency gains and leaving the non-adherents out in the cold. 
This has not happened. Were such an informal effort to succeed, the result would both more closely approximate fully cooperative negotiation and produce greater efficiency in negotiation all around.

\section{Cooperative antagonist negotiations}

\section{The concept}

In contrast with fully cooperative negotiations, many negotiations involve power. Raiffa terms such interactions negotiations among “cooperative antagonists.” He describes them as follows:

Such disputants recognize that they have differences of interests; they would like to find a compromise, but they fully expect that all parties will be primarily worried about their own interests. They do not have malevolent intentions, but neither are they altruistically inclined. They are slightly distrustful of one another; each expects the others to try to make a good case for their own side and to indulge in strategic posturing. They are not confident that the others will be truthful, but they would like to be truthful themselves, within bounds. They expect that power will be used gracefully, that all parties will abide by the law, and that all joint agreements will be honored.

Raiffa assumes that in this passage he is correctly describing most of the students he has taught negotiation and most of the readers of his book, as well as himself when he enters into negotiation in most situations. Most importantly for the readers of the book, he is describing the people they will meet across the table in negotiation. Descriptively, he is portraying the modal norm, in the sense of the most likely person any negotiator will meet across the table. Normatively in the moral sense, he conveys through his tone in this passage that these are individuals and motives with which he feels at least relatively morally comfortable.

Raiffa's concepts of strategic posturing, bounded truthfulness, and the graceful use of power, however, signal strongly that we are no longer in ideal deliberative territory, where power should be absent and where mutual respect should prevail. To clarify the 
difference between fully cooperative and cooperative antagonist negotiations, it is worth quoting at some length from Raiffa’s section on "Strategic Misrepresentations.”

Let's say that in the course of negotiations, Mr. A demands in no uncertain terms that Commissioner Daniels be dismissed. Ms. C protests equally strenuously that her side will never agree to such a move. This is a strategic misrepresentation: [C's client actually] wants to get rid of Daniels, but [A's client] doesn’t know it. Ms. C later “reluctantly” backs down...and gets Mr. A to make some concessions....

What behavior is appropriate in such a situation? I am not a cynical person, but I suspect that in the real world most [where does it go?] negotiators [in Mrs. C’s position] could exact a price from [A] for getting rid of Daniels. ...[Some suggest that] although it would be inappropriate for Ms. C to say that she wants to keep Daniels, it would be all right for her to intimate that she wants to keep him.... Is this sort of misrepresentation any more acceptable? I myself would not feel comfortable engaging in such deceptions, either by direct statement or by intimation; but I might do so in a real-world context if the cause I was representing were important enough. (cite, emphasis in original)

Raiffa conveys several messages in this passage. The first is that strategic misrepresentation (lying, directly or even by implication) is morally wrong; this is why he himself would not feel "comfortable" engaging in this behavior. The second is that for Raiffa, as for most of us, morality at the borderline is a luxury good -- one we want if we do not have to pay too much for it in other moral values (harming an important “cause”) or perhaps even in material values. The third, most subtle message, signaled by his evocation of what would probably happen in the "real world," suggests what later commentators make explicit, that certain contexts, with understood "rules of the game," evoke a "role morality” less stringent than ordinary morality but acceptable, even 
admirable in a way, in that context. ${ }^{31}$ Raiffa makes it clear that in the real world that he knows, this kind of strategic misrepresentation is expected in many negotiations.

The interaction between cooperative antagonists does not meet deliberative criteria. Strategic posturing and bounded truthfulness are both forms of misrepresentation, which is a form of force that deeply undercuts genuine mutual justification. The use of power, no matter how graceful, places these negotiations beyond deliberative limits.

\section{Negotiation and bargains, deliberation and arguing}

Both everyday usage and textbooks on negotiation define negotiation to include the two forms distinguished here as “deliberative” and "cooperative antagonist” negotiation. The Oxford English Dictionary defines the verb "to negotiate" as "to communicate or confer (with another or others) for the purpose of arranging some matter by mutual agreement; to discuss a matter with a view to some compromise or settlement.” Cramton and Dees define a negotiation as "any situation in which two or more parties are engaged in communications, the aim of which is agreement on terms affecting an exchange, or a distribution of benefits, burdens, roles, or responsibilities” (1993, 362). Neither of these definitions stresses conflict in interests among the parties. Placing a greater stress on conflict and implicitly on the self-interested motivations of the parties, Lax and Sebenius define a negotiation as "a process of potentially opportunistic interaction by which two or more parties, with some apparent conflict, seek to do better through jointly decided action than they could otherwise” $(1986,11)$. Their phrase “apparent conflict,” however, includes incompletely theorized agreements and integrated solutions, which produce agreement by respectively avoiding and resolving the conflict.

By contrast, the O.E.D. defines the verb "to bargain" as "to try to secure the best possible terms; to haggle over terms," and then defines "to haggle” as "to cavil, wrangle,

\footnotetext{
31 Throughout the book Raiffa struggles with the problems of “dissimulation,” "deception," "strategic misrepresentation," and straight out "lying," trying to accommodate some kinds of deception in negotiation but not others. He is so socially sure-footedly that his suggested compromises feel reasonably moral as well as obviously natural. But he does not explore his implicit moral criteria.
} 
dispute as to terms; esp. to make difficulties in coming to terms...." ${ }^{32}$ Here the elements of conflict are clear, as each side tries to secure from the other the best possible outcome for itself. The word "haggle” particularly connotes "dispute," with each party making "difficulties" for the other. In everyday usage a bargain connotes a zero-sum interaction with fixed preferences. It also connotes a simpler interaction than a negotiation, involving fewer (perhaps only one or two) issues and a truncated or non-existent exploration of alternatives. We might define a bargain as a subcategory of cooperative antagonist negotiation, that is, a zero-sum compromise, achieved through bidding, in which the power of withdrawal from a potential agreement plays a critical role. In bidding, one party makes an offer, the other accepts or makes a counteroffer, and the first either accepts or makes a further counteroffer, until the two either reach or fail to reach agreement. ${ }^{33}$ In a classic bargain, I want to give you as few apples as possible for as many of your oranges as I can get and you want to give me as few oranges as possible for as many of my apples as you can get. A bargain so conceived is the least deliberative of any form of negotiation.

Yet even in a classic bargain, exemplified by haggling at a bazaar, each party gets something it prefers to the status quo ante, or else the bargain will not be consummated. Parties to a bargain still aim “ultimately, at agreed joint action” (Goodin and Brennan 2001, 267). In some cases, a bargain also creates greater self- and mutual understanding, as each party's probes and counter-probes assess the relative intensity of their desires. Even in the process of haggling, both you and I can come to understand better how much we each want what we want as well as the costs to us, given the other's desires, of getting what we want. In practice, bargains among cooperative antagonists can sometimes also create a form of solidarity based on the mutual respect of individuals who know that their counterparts understand them and their own situation realistically.

A negotiation may include one or more bargains, but it is also a more fully communicative interaction, originating with perceived conflict and aimed at agreement,

\footnotetext{
32 To bargain: "To treat with any one as to the terms which one party is to give, and the other to accept, in a transaction between them; to try to secure the best possible terms; to haggle over terms." To haggle: "To cavil, wrangle, dispute as to terms; esp. to make difficulties in coming to terms or in settling a bargain; to stickle” (Oxford English Dictionary, $2^{\text {nd }}$ ed.).

33 Thanks to Phillip Petit for the concept of "bidding."
} 
that ideally includes some features of deliberative negotiation, especially the integrative attempt to explore beyond the original surface preferences of each party with the purpose of uncovering some features of their preferences and interests that are not zero-sum. When theorists use the term "bargain" or "bargaining” to denote negotiation, they restrict the meaning of negotiation to cooperative antagonist negotiation.

When theorists use the term "arguing” to denote deliberation, by contrast, they usually mean to connote disagreements of opinion on matters of principle or the common good. In so doing, they restrict the meaning of deliberation to classic deliberation. ${ }^{34}$ Posing an opposition between "bargaining” and “arguing” (e.g. Elster 1986) thus excludes from consideration convergence, incompletely theorized agreements, integrative negotiations, and fully cooperative negotiations.

\section{Mixed forms}

In many interactions in practicing democracies, the various forms of deliberation, bargaining, and negotiation intermix relatively seamlessly. Classic deliberation, convergence, and the three forms of deliberative negotiation work well with one another, making it easy to weave back and forth between them. It is harder, but not impossible, to integrate classic deliberation with the bargains and negotiations of cooperative antagonists.

\section{Integration among forms of deliberative negotiation}

Fully cooperative partners, dedicated to a fair outcome, find it easy to move back and forth between integrative negotiation and distributive negotiation because they know that their partners will not exploit at the distributive stage the information disclosed and the trust created in the fact-finding and joint exploration stage. This capacity for easy mutual transition characterizes all of the forms of deliberative negotiation.

Sometimes these forms will be intermixed in the natural course of deliberation in ways that are hard to sort out. The U.S. Sentencing Commission's agreement to use average past practice for its sentencing guidelines (Sunstein 1995, 1744) exemplifies this

34 Thomas Risse is an exception, including in “arguing” both classic deliberation and the problem-solving of integrative negotiation $(2000,2)$. 
mixing of forms within deliberative negotiation. Strictly speaking, that process produced a pure incompletely theorized agreement only when past practice on a specific sentence matched exactly what each member of the commission considered right within his own theory of sentencing. The process in fact probably generated many outcomes that some members considered wrong from their own perspective but decided to live with for the sake of getting an agreement they considered better than the status quo. In these cases, the outcome was not an incompletely theorized agreement (no one loses; no zero-sum game) but a (relatively) fully cooperative distributive compromise (each loses something; a zero-sum game). It seems almost certain that the process as a whole mixed pure incompletely theorized agreements with fully (or relatively fully) cooperative distributive negotiations.

\section{Integrating deliberative and cooperative antagonist negotiation}

It is harder to integrate the deliberative and the cooperative antagonist forms of negotiation. This integration comes in two kinds, sequential and mixed.

\section{a) Sequential integration}

Negotiation theorists suggest one version of sequential deliberation, in which the first stage is problem-solving or the search for joint gains (deliberation and deliberative negotiation), and the second stage distributive bargaining to divide those gains (cooperative antagonist negotiation). ${ }^{35}$ Some even suggest having “different negotiators deal with the two aspects separately” (Risse 2000, 21, citing Zintl 1992 and Mayntz 1997), engaging in joint problem solving until the group can no longer produce joint gains, then consciously and clearly shifting to a more competitive mode of interaction.

In another version of sequential negotiation, in which the first stage is more classically deliberative, producing a joint agreement about the principles, norms, and rules that will structure the second stage (Scharpf, 1997). The deliberation structures the negotiation, for example by ruling out options, defining the situation, or, on a more macro level, selecting the partners to the negotiation and setting the rules of the game (see Risse 2000). This deliberation can set the understanding of

35 Lax and Sebenius 1986. 
fair dealing that will govern the second stage. It can also authorize that second stage. The second stage is again one of cooperative antagonist distributive negotiation. In both sequences the first moves are deliberative and the second ones cooperative antagonist. ${ }^{36}$

\section{b) Intermixed integration}

Deliberation can also be intertwined with cooperative antagonist negotiations. Philip Pettit points out that "the contractual bid that I make in discoursing with you about the terms on which some arrangement ought to be set up between us" does "nothing to restrict discourse between us” $(2001,74)$. Katharina Holzinger comments on the prevalence of such mixes: in theory a "pure conflict of interest (free of all factual and normative disagreements) could be resolved by pure bargaining [cooperative antagonist negotiation]; however, a conflict of interest will rarely be free of normative and factual disagreement, and thus arguing [classic deliberation on the merits] is also needed” throughout the negotiation. ${ }^{37}$

Even in international politics "truth-seeking arguing” (Risse 2000) can play an important role in what is primarily a negotiation among cooperative antagonists. ${ }^{38}$ In 1990, for example, Mikhail Gorbachev entered negotiations with James Baker determined to oppose the entry of East Germany into NATO. Yet in the course of the negotiations Baker convinced Gorbachev on the merits that a united Germany would be

\footnotetext{
36 Habermas has also enunciated a slightly different "two-stage process of argument consisting of justification followed by application of norms" ([1991] 1993, 36). At the level of justification, the polity is dealing with "generalizable interests," the principle of universalization governs, and those affected decide in an open and free discussion among equals on the basis of each taking the internal perspective of the affected others. This is "a problem-solving procedure that generates convictions," not collective decisions ([1990] 1993, 158). At the level of application, the polity is dealing with "practical interests," the principle of appropriateness governs, and judges or similar parties make decisions on the basis of already justified norms. This stage produces decisions.

${ }^{37}$ Holzinger 2004, 200, emphasis in original. Holzinger reports in detail on the mixed nature of deliberation and bargaining within one failed cooperative antagonist negotiation. This negotiation, over siting an incineration plant, seems to have had some deliberative moments within a primarily cooperative antagonist negotiation. A government-sponsored mediation, it had more speech acts coded as arguing than as bargaining, a miniscule number of bargaining acts coded as threats, and few coded as promises. Moreover, about 30 percent of the participants reported that they changed some of their beliefs on "important factual issues" (although none changed their positions). See also Elster 1995 on mixed acts.
}

${ }^{38}$ See also Risse-Kappen1996, 268 on the norms of the "non-use of force and coercive power" in international cooperation among democracies. 
less threatening to Russia within NATO than outside it (Risse 2000, 26, citing Zelikow and Rice 1995). This agreement was part of a larger negotiation in which the partners acted like cooperative antagonists, with Baker giving Gorbachev assurances, for example, that no foreign troops would be stationed in East Germany (Goldgeier 1999, 16).

Mixed negotiations take place in matters of value as well as material self-interest. In Germany, for example, legislators settled temporarily a controversy over embryonic stem cell research by allowing existing stem cell lines to be used (giving the scientists some of what they wanted) but prohibiting the use of new stem cell lines (giving those opposed to the use of embryos some of what they wanted). ${ }^{39}$ On the surface this might look like an incompletely theorized agreement. For some members of the parliament the result may have been genuinely integrative. Yet it seems that if power had not been relatively equally balanced, either side would have happily imposed its values on the other. For most participants the outcome was probably a compromise negotiated among cooperative antagonists. If we distinguish between "rhetorical reason-giving” and "deliberation" on the criterion of whether or not the actors are prepared to change their own beliefs and be persuaded by the better argument (Risse 2000), in this setting few members of parliament were likely to have been persuaded by the others. The occasion seems to have reflected a good deal of prior cooperative antagonist negotiation with a little classic deliberation and perhaps deliberative negotiation mixed in. ${ }^{40}$

Perhaps ironically, in actual democracies working toward a binding decision, negotiations, even among cooperative antagonists, may produce more self-understanding and mutual understanding than the processes of classic deliberation, in which each party aims a consensus on the common good. Listening to understand and to put oneself in the

\footnotetext{
${ }^{39}$ Holzinger 2005; see also Goodin and Brennan 2001 on bargaining over beliefs. The German compromise on stem cells was the same as that reached by President George W. Bush in the U. S.

40 Holzinger reports on the parliament's plenary debate over stem cell research that although coders categorized 1775 speech acts as "arguing" and only 8 as "bargaining," the acts coded as arguing included "not many" justifications of positions and "no dialogue" $(2005,250)$. In this context it would be a mistake to consider "arguing" deliberative. Because the issue in the German legislature would eventually be decided by majority vote and because the plenary, being public, served primarily to present the different positions to the public, one would expect more rhetorical reason-giving than willingness to change one's mind. See Elster 1995, 1998 and Chambers 2004, as well as the empirical work of Ulbert and Risse 2005, on the contribution of publicity to position-taking and grandstanding, in contrast to listening and trying to imagine solutions that meet more people's needs.
} 
shoes of the other is a hallmark of good deliberation. In classic deliberation the incentives in practice to listen in this way are moral and sympathetic. It is the duty of each participant to listen to the others, strive to understand them, and attempt to craft a mutually recognizable and acceptable common good. Each participant ideally adds to this somewhat Kantian duty a moral character psychologically attuned to understanding others, experiencing empathy, and being not only willing but able to envisage herself in the others' position. ${ }^{41}$ In practice, these moral and psychological incentives are sometimes insufficient to motivate the necessary behavior. In both deliberative negotiation and cooperative antagonist negotiation, by contrast, each party has a strong incentive to understand at least some of the other party's motivations, preferences, and interests, because this understanding allows both to craft a solution that meets more of each of their needs. Cognitive perspective taking, which emphasizes thinking about the other's interests, seems to produce more joint gains in negotiation than emotional empathy. ${ }^{42}$ Even cooperative antagonist negotiation may produce more mutual respect than do assemblies in which actors discuss the common good. Studying constituent assemblies, Elster $(1998,100)$ found that behind closed doors the political actors engaged in more bargaining than in open assemblies. Coding legislative transcripts in four countries, Steiner and his colleagues (2004) found that in closed arenas legislators also expressed more respect toward the claims of others than in open assemblies. It would not be far-fetched to conclude that the processes of bargaining and negotiation generate more actual respect (as well as external expressions of respect) for the claims of others than do formal open "deliberative" bodies. ${ }^{43}$ In bargains and other cooperative antagonist

\footnotetext{
${ }^{41}$ See Baeir 1987 and Blum 1982 for arguments that the Kantian morality of duty must be supplemented with a more emotion- and character-based morality. See Krause 2008, Hall 2007 and Morrell forthcoming for the positive role of emotions in deliberation.

42 In studies that primed for two types of perspective-taking, the cognitive ("Try to understand what they are thinking") and emotional ("Try to understand what it would feel like"), the participants primed for cognitive perspective-taking did better than the controls in a series of different kinds of negotiations (some potentially integrative and some mixed integrative and distributive, or zero-sum), while those primed for emotional perspective-taking (termed "empathy" in their description) did either insignificantly better or in some cases worse than the controls (Galinsky, Maddux, Gilin and White 2008).

43 Future research may well complete the empirical link, showing directly that bargaining and the negotiation of conflict produce more mutual statements of respect and understanding for others' positions than do the acts that are coded as "deliberation" in these studies.
} 
negotiations both parties have at least self-interested incentives to pay attention to what the others want and need.

\section{Normative criteria for judging cooperative antagonist interactions}

From the perspective of deliberative democracy, cooperative antagonist negotiations are the more legitimate the more closely they approximate the conditions of ideal deliberative negotiations: absence of coercive power, a base solely in mutual justification, as well as reciprocity, mutual respect, freedom, and equality among the partners. When the context shifts from one of interests that can be conceived as common to one of insuperably conflicting interests, however, democrats have to think differently about how to legitimate that conflict. Two possible tools in this endeavor are the effort to equalize power and the legitimation of a role morality particular to the conflict.

\section{Equal power}

Cooperative antagonist negotiations can be conceived as an extension of the logic of the vote, that is, as legitimated by an equal exercise of power in a competitive democratic struggle. Rather than the majority simply outvoting the minority, the majority and minority negotiate from their relative positions of strength (based ideally only on the sum of their equal individual votes) to an outcome acceptable to both, given those relative positions. Although the number of votes my position can command on a particular issue may be smaller than the number of votes yours can command, you may compromise with me on the issue in question if my forces will join yours against another group on another issue.

Yet it is not easy to conceive how to apply the norm of equal power to cooperative antagonist negotiation. Democratic theorists seem to agree in the abstract on the regulative ideal of equal power among bargaining partners, whether in direct assemblies, legislatures, or legislatively-endorsed extra-parliamentary venues. In Habermas's words, democracies require, in addition to deliberation, bargains that deploy “threats and promises...material resources, manpower and the like,” but the "bargaining 
power should at least be disciplined by its equal distribution among the parties." 44 Habermas also argues that for the bargains to be "fair," their procedures should "provide all the interested parties with an equal opportunity for pressure, that is, an equal opportunity to influence one another during the actual bargaining, so that all the affected interests can come into play and have equal chances of prevailing” (166-7).

Equal power, however, is even harder to achieve in bargaining or negotiation than in voting. Every feature that could affect the cost of leaving or not entering the negotiation affects bargaining power, including one's best alternative to a negotiated agreement and the effects of the status quo on one's position. Possessing information and the resources to gather information, not requiring an immediate resolution, and many other factors all affect bargaining power. Moreover, as with the vote, equal power can be defined either individually or in context. An actor may individually have equal power with all other individuals, but if that actor is in a minority, particularly a permanent minority, Habermas's "equal opportunity for pressure" will not translate into an equal or even a proportionate chance of "prevailing." Nor will it even translate into outcomes in which all interests have equal consideration. With equal individual power but without sufficient allies in a given context, the interests of a participant may be given infinitesimal or no consideration. For the member of a minority, the different principles of equal opportunity, equal power, equal outcomes, and equal satisfaction can each produce different outcomes, both in majority rule and in bargaining (Beitz 1989, Mansbridge 1980). Because the principles of political equality are multiple and indeterminate (Beitz 1989), what constitutes equality in the opportunity for pressure or the chance of prevailing will often be intrinsically contestable.

For example, equal power as between the two sides of a controversy (that is, equal numbers and strength of allies) will tend to create an environment in which each side is willing to hammer out some form of compromise that respects the other's deepest commitments (as in the German stem cell decision). But equal power as between two sides of a controversy often produces quite different results from equal individual power, in which the greater numbers prevail. While balance may produce the more deliberative

44 Habermas [1992] 1996, 165-66, quoting Elster 1991 on threats and promises. See also pp. 108-9. The use of "threats" as well as promises indicates that the bargains to which Habermas refers take place among cooperative antagonists, not fully cooperative partners. 
results, based on each side justifying its position to the other through considerations the others are likely to accept, from the more adversary perspective of an authorized struggle, equal individual power is democratically fairer. The question of the terms on which cooperative antagonist interactions can be integrated with deliberative ones remains open for further exploration.

\section{Role morality}

Human social life sometimes cordons off certain arenas of interaction, permitting within these arenas a specific role-morality particular to the rules of a specific "game." The standard analogy is the poker game, where strategic misrepresentation is an accepted part of the game. James J. White, among others, argues that negotiation is like a poker game: “To conceal one's true position, to mislead an opponent about one's true settling point, is the essence of negotiation." ${ }^{45}$ A handbook on business negotiation suggests that "An individual who confuses private ethics with business morality does not make an effective negotiator. A negotiator must learn to...subordinate his own personal sense of ethics to the prime purpose of securing the best deal possible for the client.” (Beckman 1977, quoted in Lax and Sabenius 1986, 146). ${ }^{46}$

Writers in this "role-morality" school insist that negotiation rightly partakes of an amorality appropriate to the market, although like the market it should conform to the law, including the law of fraud. Cramton and Dees quote Anacharsis as writing in 600 BC: "The market is the place set apart where men may deceive one another" $(1993,360)$. In ancient Greece, Hermes, who stole his brother's cattle and lied about it, was the patron god of merchants (idem). In markets based on repeated interactions, however, deceit and theft play a greatly reduced role. Indeed, deceit and theft produce inefficient markets, just as they produce inefficient negotiations. Firms are efficient in part because they can institutionalize repeated interactions and exercise both formal and informal sanctions against deceit. But because in certain single-event transactions it is hard both legally and

45 White 1980, 928; see also Carr (1968, 145), allowing “cunning deception” and “concealment.”

46 In politics, similarly, Machiavelli argued that "great things" have been done by those who have "little regard for good faith” (Prince ch. $182^{\text {nd }}$ sentence). 
socially to prevent the subtle forms of deceit, in such markets those forms of deceit have become widely accepted as the "rules of the game."

Many British and American legal theorists argue that in the adversary legal system of these countries strategic misrepresentations are an accepted part of the game. ${ }^{47}$ A weaker version of this theory seems to apply to legislative behavior, at least in the United States. Legislatures establish certain rules of interaction whose breach they sanction, or claim to sanction. But other forms of strategic action, such as parliamentary maneuvering, are not only allowed but even admired as a skill among some practitioners of the craft.

Arthur Applbaum argues that if "rules of the game" are invoked to justify a role morality that permits what would otherwise be morally prohibited, the game in question must meet certain criteria. These criteria are stringent and unlikely to be satisfied outside of certain literal games. He writes, “A player in a game of strategy is morally permitted to take an action against a target, so as to restrict the target's liberties or set back the target's interests" only when 1) the rules of the game permit such action, 2) "the rules permitting such action are necessary for the continued success or stability of the game as a mutually advantageous cooperative venture,” 3) “the game is a mutually advantageous cooperative venture in that, considering all benefits and burdens, including the baseline alternative of there being no game, the game provides all its players [that is, "those who voluntarily seek the venture's benefits”] positive expected benefits,” 4) the target receives “a just share of the venture’s benefits and burdens," and more generally the venture “distributes benefits and burdens justly to its players," while imposing "no unjust externalities on those who are not players," and 5) "preferring the existence of the game with its benefits and burdens to there being no game, the target has voluntarily sought the game's benefits... as an uncoerced and informed choice of action where not to benefit is both possible and costless." 48

To the degree that the strategic "rules of the game" in a given context meet Applbaum's criteria, one can imagine their being deliberatively authorized as acceptable

47 E.g., Curtis: "freedom from the strict bonds of veracity" is one of the "chief assets of the profession" and that "one of the functions of the lawyer is to lie for his client" $(1951,9)$.

48 Applbaum 1998, 123. See also Lax and Sebenius 1986. 
practices. One key criterion is that the presence of such a game must provide all of its players with positive expected benefits compared to the absence of the game. Advocates for the adversary legal system argue that, within guidelines designed to protect both parties and induce fairness, the equilibrium produced by the lawyers on each side bending their skills to the utmost to promote their clients' interests results in greater justice and a greater protection of individual liberties than in other legal systems. It is not at all clear, however, how strategic misrepresentation in negotiation helps further either justice or individual liberties.

The main argument for allowing the strategic misrepresentations that now take place in adversary legal systems and market negotiations seems to be that it is not in fact possible to monitor intent or private knowledge. Banning behaviors that cannot be monitored simply sets up ethical individuals for exploitation. Better to accept openly, as part of the game, the behaviors that cannot be monitored, so that ethical individuals, adopting a role-morality suitable to this specific arena, have an even playing field with the unethical. ${ }^{49}$ As White puts it, the role-morality allowed in such cases "may simply arise from a recognition by the law of its limited power to shape human behavior. By tolerating exaggeration and puffing in the sales transaction, by refusing to make misstatement of one's intention actionable, the law may simply have recognized the bounds of its control over human beings" (White 1980, 934).

When such designated arenas for role-morality exist but are implicitly rather than explicitly designated, practical advice for the ethical would be to engage in "hunting for the rules of the game as the game is played in that particular circumstance" (White 1980, 929). It is easy, White argues, to discover that one is playing in a designated arena (in which, for example, full truthfulness is not required) when the implicit "rules of the game are explicit and well developed,” as they often are in legal advocacy (934).

In legislatures, strategic misrepresentation is as inefficient as it is anywhere else. Nor are the individual players any happier to have their autonomy and agency undermined by deceit. Repeated interaction therefore produces, as always, a set of rules making many misrepresentations illegal. Yet openings for strategic maneuvering remain.

\footnotetext{
49 See Lipsey and Lancaster 1956-57 and later writers on the problem of the "second best": "When others act non-morally, there may be an obligation to deviate...from the behavior that would have been optimal if adopted by everybody" (Elster 1986, 119).
} 
The resulting authorized departures from fully cooperative negotiation do not seem to meet Applbaum’s criteria for permissible role morality. They do not benefit all participants in comparison to other viable regimes. They also distinctly contravene deliberative ideals. Free and equal interlocutors would authorize these cooperative antagonist practices only when in practice the moral costs of trying to ban their use are less than the costs of allowing them. This might turn out to be much of the time.

\section{Conclusion}

This paper argues that classic deliberation is deeply compatible with several forms of negotiation, which are termed here “deliberative negotiation.” These forms include incompletely theorized agreements, integrative negotiations, and fully cooperative distributive negotiations. These forms are ideally based on mutual justification, mutual respect, and a search for both fair terms of interaction and fair outcomes. Again ideally, they do not involve coercive power. These deliberative forms of negotiation are in some tension with, but in practice can co-exist constructively with, cooperative antagonist negotiation, in which participants oriented primarily to success use coercive power, including strategic misrepresentation, to achieve their ends.

Deliberative forms of negotiation not only can approach the deliberative criteria for legitimacy, they are also efficient. The mutual disclosure, joint fact-finding, and joint exploration of possibility that they promote usually generate joint gains. By contrast, cooperative antagonist negotiations fail to approach deliberative criteria and are relatively inefficient. They focus on dividing a fixed pie and encourage incentives and motivations that usually impede deliberative negotiations. For these reasons, in an ideal world free and equal citizens devising democratic decision-making processes would not authorize cooperative antagonist negotiations. However, in a world in which some citizens predictably will use their power resources in negotiation and will not always act on the basis of mutual justification, mutual respect, and a search for fair terms of interaction and fair outcomes, those citizens might well authorize cooperative antagonist negotiations constrained as much as possible by institutions that tend to equalize power and by legal requirements for honesty and fair dealing. 
In analogy with the legal system, it may also be that a spirit of partisanship, trying to win within certain rules of the game, along with an active spirit of contest and opposition, would in practice produce just the organization and protection of ideas that lively deliberation demands. ${ }^{50}$ If so, rather than being no more than a compromise with reality, cooperative antagonist negotiation would positively promote democratic values.

${ }^{50}$ For the virtues and ethics of partisanship, see Muirhead 2006, Rosenblum 2008; for the need actively to promote adversarial debate, Manin 2005. 


\section{$\underline{\text { References }}$}

Applbaum, Arthur I. 1998. Ethics for Adversaries: The Morality of Roles in Public and Professional Life. Princeton: Princeton University Press.

Bachrach, Peter and Morton Baratz, 1963. "Decisions and Non-Decisions: An Analytical Framework," American Political Science Review 57: 632-642.

Baier, Annette C. 1987. "Hume, the woman's moral theorist?" in Eva Kittay and Diana Meyers, eds., Women and Moral Theory. Totowa, N.J.: Rowman and Littlefield.

Bazerman, Max H., Jonathan Baron, and Katherine Shonk. 2001. "You Can't Enlarge The Pie": Six Barriers To Effective Government. Cambridge, MA: Basic Books.

Beitz, Charles. 1989. Political Equality: An Essay in Democratic Theory. Princeton: Princeton University Press.

Benhabib, Seyla. 1996. “Toward a Deliberative Model of Democratic Legitimacy. In Seyla Benhabib, ed. Democracy and Difference. Princeton: Princeton University Press.

Blum, Laurence A. , "Kant and Hegel's moral rationalism: A feminist perspective," Canadian Journal of Philosophy 12 (1982): 287-302.

Bohman, James. 1998. "Survey Article: The Coming of Age of Deliberative Democracy.” Journal of Political Philosophy 6 (4): 400-425.

Breyer, Stephen G. 1988. “The Federal Sentencing Guidelines and the Key Compromises upon Which They Rest.” Hofstra Law Review 17 (1): 1-50.

Carr, Albert Z. 1968. “Is Business Bluffing Ethical?” Harvard Business Review JanFeb: 143-153.

Chambers, Simone. 1996. Reasonable Democracy: Jürgen Habermas and the Politics of Discourse. Ithaca, N.Y.: Cornell University Press.

Chambers, Simone. 2003. "Deliberative democratic theory.” Annual Review of Political Science, 6: 307-326.

Chambers, Simone. 2004. "Behind Closed Doors: Publicity, Secrecy, and the Quality of Deliberation.” Journal of Political Philosophy, 12 (4): 389-410.

Cohen, Joshua. 1989. 'Deliberation and Democratic Legitimacy.' In Alan Hamlin and Philip Pettit, eds., The Good Polity, Blackwell, Oxford, pp. 17-34. 
Cohen, Joshua. 1996. "Procedure and Substance in Deliberative Democracy." In Seyla Benhabib, ed. Democracy and Difference. Princeton: Princeton University Press.

Cramton, Peter C. and J. Gregory Dees. 1993. "Promoting Honesty in Negotation: An Exercise in Practical Ethics.” Business Ethics Quarterly 3: 359-394.

Curtis, Charles P. 1951. “The Ethics of Advocacy.” Stanford Law Review 4: 3-23.

Dryzek, John S. 2000. Deliberative Democracy and Beyond: Liberals, Critics, Contestations. Oxford: Oxford University Press.

Elster, Jon. 1986. "The Market and the Forum: Three Varieties of Political Theory.” In Foundations of Social Choice Theory, Jon Elster \& Aanund Hylland eds. Cambridge: Cambridge University Press.

Elster, Jon. [1991] 2000. "Arguing and Bargaining in Two Constituent Assemblies.” University of Pennsylvania Journal of Constitutional Law. 2 (2): 345-421.

Elster, Jon. 1995. “Strategic Uses of Argument.” In Kenneth Arrow et al., eds., Barriers to Conflict Resolution. N.Y.: Norton.

Elster, Jon. 1998. "Deliberation and Constitution Making." In Deliberative Democracy, ed. Jon Elster. Cambridge: Cambridge University Press.

Estlund, David. 2006.

Fisher, Roger. 1985. “A Code of Negotiation Practices for Lawyers.” Negotiation Journal 1:105-110, reprinted in Carrie Menkel-Meadow and Michael Wheeler, eds., What's Fair? Ethics for Negotiators. San Francisco: Jossey-Bass/Wiley.

Fisher, Roger, William Ury, and B. Patton. 1991. Getting to Yes: Negotiating Agreement without Giving In. ( $2^{\text {nd }}$ ed.) New York: Penguin.

Follett, Mary Parker. [1925] 1942. "Constructive Conflict.” In Dynamic Administration: The Collected Papers of Mary Parker Follett, Henry C. Metcalf and L. Urwick, eds. New York: Harper.

Frank, Robert H. 1988. Passions within Reason. New York: Norton.

Frank, Robert H., Thomas Gilovich, and Dennis Regan. 1993. "Does Studying Economics Inhibit Cooperation?” Journal of Economic Perspectives 7(2): 159-71.

Galinsky, Adam D., William W. Maddux, D. Gilin and J.B. White, J.B. 2008. "Why it Pays to Get Inside the Head of Your Opponent: The Differential Effects of PerspectiveTaking and Empathy in Negotiations.” Psychological Science. 19(4): 378-384. 
Gauthier, David P. 1986. Morals by Agreement. Oxford: Oxford University Press.

Goldgeier, James M. 1999. Not Whether But When: The U.S. Decision to Enlarge NATO. Washington, D.C.: Brookings Institution Press.

Goodin, Robert E. 1996. Institutionalizing the public interest: The defense of deadlock and beyond. American Political Science Review, 90(2): 331-343.

Goodin, Robert E. 2005. “Sequencing Deliberative Moments.” Acta Politica 40: 182196.

Goodin, Robert E. and Geoffrey Brennan. 2001. “Bargaining over Beliefs.” Ethics 111 (2): 256-277.

Gutmann, Amy and Dennis Thompson. 1996. Democracy and Disagreement. Cambridge, MA: Harvard University Press.

Gutmann, Amy and Dennis Thompson. 2004. Why Deliberative Democracy? Princeton: Princeton University Press.

Habermas, Jürgen. [1962] 1989. The Structural Transformation of the Public Sphere: An Inquiry into a Category of Bourgeois Society. Trans. Thomas Burger and Frederick Lawrence. Cambridge, Mass.: MIT Press.

Habermas, Jürgen. [1973] 1975. Legitimation Crisis. Trans. Thomas McCarthy. Cambridge, MA: MIT Press.

Habermas, Jürgen. [1981] 1984. The Theory of Communicative Action, vol. I: Reason and the Rationalization of Society. Trans. Thomas McCarthy. Boston: Beacon Press.

Habermas, Jürgen. 1982. “A Reply to my Critics.” In John B. Thompson and David Held, eds., Habermas: Critical Debates. Cambridge, Mass.: MIT Press.

Habermas, Jürgen. [1983] 1990. Moral consciousness and communicative action. Trans. Christian Lenhardt and Shierry Weber Nicholsen. Cambridge, Mass.: MIT Press.

Habermas, Jürgen. 1989. "Morality and Ethical Life: Does Hegel's Critique of Kant Apply to Discourse Ethics?” Northwestern University Law Review 83 (1): 38-53.

Habermas, Jürgen. [1990] 1993. "Morality, Society, and Ethics: An Interview with Torben Hviid Nielsen." In Justification and Application: Remarks on Discourse Ethics. Trans. Ciaran P. Cronin. Cambridge, MA: MIT Press. 
Habermas, Jürgen. [1991] 1993. "Remarks on Discourse Ethics." In Justification and Application: Remarks on Discourse Ethics. Trans. Ciaran P. Cronin. Cambridge, MA: MIT Press.

Habermas, Jürgen. [1992] 1996. Between Facts and Norms: Contributions to a Discourse Theory of Law and Democracy. William Rehg, trans. Cambridge, MA: MIT Press.

Hall, Cheryl. 2007. "Recognizing the Passion in Deliberation: Toward a More Democratic Theory of Deliberative Democracy." Hypatia: A Journal of Feminist Philosophy 22 (4): 81-95.

Hazard, Geoffrey C. 1981. “The Lawyer’s Obligation to be Trustworthy when Dealing with Opposing Parties.” South Carolina Law Review 33 (2): 181-96.

Holmes, John G., Dale T. Miller, and Melvin J. Lerner. 2002. "Committing Altruism under the Cloak of Self-Interest.” Journal of Experimental Social Psychology 38: 144151.

Holzinger, Katharina. 2004. "Bargaining Through Arguing: An Empirical Analysis Based on Speech Act Theory.” Political Communication 21(2): 195 - 222.

Holzinger, Katharina. 2005. “Context or Conflict Types: Which Determines the Selection of Communication Mode?” Acta Politica 40: 239-254.

Kaboolian, Linda. 2006. Win-Win Labor-Management Collaboration in Education. Mt. Morris, IL: Education Week Press.

Knight, Jack and James Johnson. 1997. "What sort of political equality does democratic deliberation require?” In Deliberative Democracy, James Bohman and William Rehg eds. Cambridge, Mass.: MIT Press.

Krause, Sharon R. 2008. Civil Passions: Moral Sentiment and Democratic Deliberation. Princeton: Princeton University Press.

Langevoort, Donald C. 1999. "Half-Truths: Protecting Mistaken Inferences by Investors and Others.” Stanford Law Review 52: 88-125.

Lax, David A and James K Sebenius. 1986. The Manager as Negotiator. New York: Free Press.

Lax, David A. and James K. Sebenius. 2006. 3-D Negotiation: Powerful Tools to Change the Game in Your Most Important Deals. Boston, Mass.: Harvard Business School Press.

Lewicki, Roy J. and Robert J. Robinson. 1998. "Ethical and Unethical Bargaining Tactics: An Empirical Study.” Journal of Business Ethics 17: 665-682. 
Lipsey R.G. and Kelvin Lancaster. 1956 - 1957. "The General Theory of Second Best.” The Review of Economic Studies 24 (1): 11-32.

Lukes, Steven. 1974. Power: A Radical View. London: Macmillian.

Machiavelli, Niccolò. 1513] 2005. The Prince. Trans. Peter Bondanella. Oxford: Oxford University Press.

Manin, Bernard. 2005. Deliberation: Why We Should Focus on Debate Rather than Discussion. Paper presented at the Program in Ethics and Public Affairs Seminar, Princeton University. Available online at: www.princeton.edu/ uchv/whatsnew/PEPA1013.pdf

Mansbridge, Jane. 1980. Beyond Adversary Democracy. New York: Basic Books.

Mansbridge, Jane. 1990. "On the Relation of Altruism and Self-Interest." In Jane Mansbridge, ed., Beyond Self-Interest, 133-143. Chicago: University of Chicago Press.

Mansbridge, Jane. 1992. “A Deliberative Theory of Interest Representation.” In Mark Petracca, ed., The Politics of Interests: Interest Groups Transformed. Boulder: Westview.

Mansbridge, Jane. 1996. “Using Power/Fighting Power: The Polity.” In S. Benhabib, ed., Democracy and Difference. Princeton: Princeton University Press.

Mansbridge, Jane. 1998. “On the Contested Nature of the Public Good.” In Woody W. Powell and Elizabeth S. Clemens, eds., Private Action and the Public Good. New Haven: Yale University Press.

Mansbridge, Jane, with James Bohman, Simone Chambers, David Estlund, Andreas Follesdal, Archon Fung, Cristina Lafont, Bernard Manin, and José Luis Martí. Forthcoming. "The Place of Self-Interest in Deliberation." The Journal of Political Philosophy.

Mansbridge, Jane and Shauna L. Shames. 2008. “Toward a Theory of Backlash: Dynamic Resistance and the Central Role of Power.” Politics \& Gender 4: 1-11.

Mayntz, Renate. 1997. Soziale Dynamik und politische Steuerung. Theoretische und methodologische Uberlegungen. Frankfurt am Main: Campus.

Menkel-Meadow, Carrie. 1990. "The Golden Rule of Candor" 138 University of Pennsylvania Law Review 761.

Menkel-Meadow, Carrie. 2004. "Introduction: What's Fair in Negotiation? What is Ethics in Negotiation?” In Carrie Menkel-Meadow and Michael Wheeler, eds., What's Fair? Ethics for Negotiators. San Francisco: Jossey-Bass/Wiley. 
Moon, Donald. 1993. Constructing Community: Moral Pluralism and Tragic Conflicts. Princeton: Princeton University Press.

Morrell, Michael E. forthcoming. Empathy and Democracy: Feeling, Thinking and Deliberation. Unpub. Ms., under review with Pennsylvania State University Press)

Muirhead, Russell. 2006. “A Defense of Party Spirit.” Perspectives on Politics, 4 (4): 713-27.

Nagel, Jack H., 1975. The Descriptive Analysis of Power. New Haven: Yale University Press.

Nino, Carlos Santiago. 1996. The Constitution of Deliberative Democracy. New Haven: Yale University Press.

Olson, Mancur. 1965. The Logic of Collective Action. Cambridge, Mass.: Harvard University Press.

Pettit, Philip. 2001. A Theory of Freedom: From the Psychology to the Politics of Agency. Oxford: Blackwell.

Pettit, Philip. 2003. "Deliberative Democracy, the Discursive Dilemma, and Republican Theory.” In James Fishkin and Peter Laslett, Debating Deliberative Democracy. Malden, MA: Blackwell. (138-162)

Posner, Richard A. 2007. Economic Analysis of Law. New York: Aspen Publishers

Raiffa, Howard. 1982. The Art and Science of Negotiation. Cambridge, MA: Harvard University Press.

Raz, Joseph. 1986. The Morality of Freedom. Oxford: Oxford University Press.

Risse, Thomas. 2000. “Let’s Argue!'”: Communicative Action in World Politics.” International Organization 54 (1): 1-39

Risse-Kappen, Thomas. 1998. "Collective Identity in a Democratic Community: The Case of NATO.” In The Culture of National Security, ed. Peter Katzenstein, pp. 357-399. New York: Columbia University Press.

Rosen, Michael. 1999. "Utopia in Frankfurt: Realism and Optimism in the Life's Work of Jürgen Habermas.” Times Literary Supplement 5034 (Oct. 8), 3-4.

Rosenblum, Nancy F. 2008. On the Side of the Angels: An Appreciation of Parties and Partisanship. Princeton: Princeton University Press. 
Scharpf, Fritz W. 1997. Games Real Actors Play: Actor-Centered Institutionalism in Policy Research. Boulder, Colo.: Westview Press.

Schmitt, Carl. [1923] 1988. The Crisis of Parliamentary Democracy, trans. Ellen Kennedy. Cambridge, MA: MIT Press.

Shell, G. Richard. 2006. Bargaining for Advantage. New York: Penguin.

Steiner, Jürg et al. 2004. Deliberative Politics in Action: Analyzing Parliamentary

Discourse. Cambridge: Cambridge University Press.

Sunstein, Cass R. 1985. “Interest Groups in American Law.” Stanford Law Review 38: 29-87.

Sunstein, Cass R. 1988. “Beyond the Republican Revival.” Yale Law Journal 97 (8): 1539-1590.

Sunstein, Cass R. 1995. “Incompletely Theorized Agreements.” Harvard Law Review, 108 (7): 1733-1772.

Sunstein, Cass R. 1996. Legal Reasoning and Political Conflict. New York: Oxford University Press.

Thompson, Dennis F. 2008. "Deliberative Democratic Theory and Empirical Political Science.” Annual Review of Political Science. 11: 497-520.

Thompson, Leigh L. 2005. The Mind and Heart of the Negotiator, $3^{\text {rd }}$ ed., Upper Saddle River, NJ: Pierson/Prentice Hall.

Ury, William L., Jeanne M. Brett, and S.B. Goldberg. 1988. Getting Disputes Resolved: Designing Systems to Cut the Cost of Conflict. San Francisco: Jossey-Bass.

Wetlaufer, Gerald B. 1996. “The Limits of Integrative Bargaining.” Georgetown Law Journal 85: 369.

Wheeler, Michael. 2004. "Swimming with Saints/Praying with Sharks." In Carrie Menkel-Meadow and Michael Wheeler, eds., What's Fair? Ethics for Negotiators. San Francisco: Jossey-Bass/Wiley.

White, James J. 1980. "Machiavelli and the Bar: Ethical Limitations on Lying in Negotiation.” American Bar Foundation Research Journal 4: 926-938.

Zelikow, Philip, and Condoleezza Rice. 1995. Germany United and Europe Transformed: A Study in Statecraft. Cambridge, Mass.: Harvard University Press. 
Zintl, Reinhard. 1992. "Kooperation und Aufteilung des Kooperationsgewinns bei horizontaler Politikverechtung.” In Arthur Benz, Fritz W. Scharpf and Reinhard Zintl, eds., Horizontale Politikverechtung: Zur Theorie von Verhandlungssystemen. Frankfurt am Main: Campus. (97-146) 